\title{
Molecular and microscopic analysis of the gut contents of abundant rove beetle species (Coleoptera, Staphylinidae) in the boreal balsam fir forest of Quebec, Canada
}

\author{
Jan Klimaszewski', Marie-Josee Morency', Philippe Labrie', Armand Séguin', \\ David Langor', Timothy Work³, Caroline Bourdon', Evelyne Thiffault', \\ David Paré', Alfred F. Newton ${ }^{4}$, Margaret K. Thayer ${ }^{4}$
}

I Natural Resources Canada, Canadian Forest Service, Laurentian Forestry Centre, 1055 du P.E.P.S., P.O. Box 10380, Stn. Sainte-Foy, Québec, Québec, G1V 4C7, Canada 2 Natural Resources Canada, Canadian Forest Service, Northern Forestry Centre, 5320-122 Street, Edmonton, Alberta, T6H 3S5, Canada 3 Département des sciences biologiques, Université du Québec à Montréal, CP 8888, Succursale Centre-ville, Montréal, Québec, H3C 3P8, Canada 4 Integrative Research Center, The Field Museum of Natural History, Chicago, Illinois, 60605-2496, U.S.A.

Corresponding author: Jan Klimaszewski (jan.klimaszewski@nrcan-rncan.gc.ca)

Academic editor: Michael Ivie | Received 18 July 2013 | Accepted 15 October 2013 | Published 20 November 2013

Citation: Klimaszewski J, Morency M-J, Labrie P, Séguin A, Langor D, Work T, Bourdon C, Thiffault E, Paré D, Newton AF, Thayer MK (2013) Molecular and microscopic analysis of the gut contents of abundant rove beetle species (Coleoptera, Staphylinidae) in the boreal balsam fir forest of Quebec, Canada. ZooKeys 353: 1-24. doi: 10.3897/ zookeys.353.5991

\begin{abstract}
Experimental research on beetle responses to removal of logging residues following clearcut harvesting in the boreal balsam fir forest of Quebec revealed several abundant rove beetle (Staphylinidae) species potentially important for long-term monitoring. To understand the trophic affiliations of these species in forest ecosystems, it was necessary to analyze their gut contents. We used microscopic and molecular (DNA) methods to identify the gut contents of the following rove beetles: Atheta capsularis Klimaszewski, Atheta klagesi Bernhauer, Oxypoda grandipennis (Casey), Bryophacis smetanai Campbell, Ischnosoma longicorne (Mäklin), Mycetoporus montanus Luze, Tachinus frigidus Erichson, Tachinus fumipennis (Say), Tachinus quebecensis Robert, and Pseudopsis subulata Herman. We found no apparent arthropod fragments within the guts; however, a number of fungi were identified by DNA sequences, including filamentous fungi and budding yeasts [Ascomycota: Candida derodonti Suh \& Blackwell (accession number FJ623605), Candida mesenterica (Geiger) Diddens \& Lodder (accession number FM178362), Candida railenensis Ramirez and Gonzáles (accession number JX455763), Candida sophie-reginae Ramirez \& González (accession number HQ652073), Candida
\end{abstract}

Copyright Her Majesty the Queen in Right of Canada. This is an open access article distributed under the terms of the Creative Commons Attribution License 3.0 (CC-BY), which permits unrestricted use, distribution, and reproduction in any medium, provided the original author and source are credited. 
sp. (accession number AY498864), Pichia delftensis Beech (accession number AY923246), Pichia membranifaciens Hansen (accession number JQ26345), Pichia misumaiensis Y. Sasaki and Tak. Yoshida ex Kurtzman 2000 (accession number U73581), Pichia sp. (accession number AM261630), Cladosporium sp. (accession number KF367501), Acremonium psammosporum W. Gams (accession number GU566287), Alternaria sp. (accession number GU584946), Aspergillus versicolor Bubak (accession number AJ937750), and Aspergillus amstelodami (L. Mangin) Thom and Church (accession number HQ728257)]. In addition, two species of bacteria [Bradyrhizobium japonicum (Kirchner) Jordan (accession number BA000040) and Serratia marcescens Bizio accession number CP003942] were found in the guts. These results not only provide evidence of the consumer-resource relations of these beetles but also clarify the relationship between rove beetles, woody debris and fungi. Predominance of yeast-feeding by abundant rove beetles suggests that it may play an important role in their dietary requirements.

\section{Keywords}

Rove beetles, Staphylinidae, Coleoptera, diet, fungivory, mycophagy, gut analysis, trophic relationship, saproxylic, boreal forest, Canada, Ascomycota, Basidiomycota, bacteria

\section{Introduction}

Rove beetles (Coleoptera: Staphylinidae) have proven to be useful indicators of forest disturbance and recovery because they are sensitive to environmental perturbations, diverse in species and trophic roles, easily sampled, and at least in central Europe and Canada, mostly readily identified using a wealth of available taxonomic tools (Bohác 1990, 1999, Pohl et al. 2008). Many staphylinid species show distinct response patterns following forest disturbances (e.g., Pohl et al. 2007, 2008, Klimaszewski et al. 2008, Work et al. 2013). For example, in a recent study of rove beetles following removal of logging residues by whole-tree harvesting in boreal balsam fir forests of Quebec, three Atheta species, Tachinus fumipennis (Say) and Tachinus frigidus Erichson were negatively affected by the removal of forest biomass, while Gabrius brevipennis (Horn), Pseudopsis subulata Herman and Quedius labradorensis Smetana were not and their catch increased (Work et al. 2013). While studies comparing species assemblages can quantify the overall effects of harvest treatments or other forest disturbances, they are often not designed to identify specific underlying mechanisms for individual species' responses. Study of trophic roles may provide useful insights into these response patterns by assessing factors such as individual predator-prey (or consumer-resource) relationships, the degree of diet specialization, and possible associations of beetles with specific microhabitats that may serve as habitat or substrate for their food resources.

Rove beetles are a diverse group exhibiting a wide variety of trophic relationships and occupying numerous microhabitats in forest ecosystems. Many Aleocharinae and Staphylininae, e.g., species of Aleochara, Philonthus, Platydracus, and Staphylinus, are voracious predators of other arthropods such as fly larvae (Klimaszewski 1984, Smetana 1995). At least some species of Scaphidiinae, Osoriinae, Tachyporinae, and Aleocharinae (Gyrophaenina) eat the flesh or spores of fungal sporocarps (Seevers 1951, Ashe 1984, Newton 1984). Oxytelinae are generally detritivores and feed on decaying plant ma- 
terial and algae (Thayer 2005, Makranczy 2006). A few Omaliinae, e.g. Eusphalerum and some other genera, are pollen-feeders (Thayer 1987, 2005). A few species, such as the aleocharine Himalusa thailandensis Pace, Klim. \& Cent., feed on live plant tissue (Klimaszewski et al. 2010). Most information on food sources of rove beetles has been obtained through observation of individual beetles in the field or laboratory, or inference from habitat associations of species. For example, some groups (e.g., Aleochara, Philonthus) that are collected in decaying mushrooms are predators of dipteran larvae that co-occur within these fungi (Klimaszewski 1984, Smetana 1995). While direct observations of feeding provide compelling evidence of dietary preferences, inferences based on habitat preferences are not definitive evidence of consumer-resource relationships. Other methods have been used to more definitively establish feeding habits of beetles including microscopical examination of gut contents (Newton 1984, Thayer 1987) and immunological methods (Dennison and Hodkinson 1983). The use of molecular techniques to investigate dietary preferences and trophic links in rove beetles is presented here for the first time, but similar techniques were used in the past to investigate invertebrate predators for multiple prey using DNA targets (Harper et al. 2005). Increasingly large databases of DNA sequences in repositories such as GenBank and MycoBank will make these techniques more and more useful for examining relationships between beetles and cryptic food items such as fungi and bacteria (Crous et al. 2004, Robert et al. 2005). For beetles that feed on organisms with relatively strict habitat requirements, such as fungal species that require lignocellulose, molecular gut analyses may lead to inferences on the importance of habitat elements such as downed deadwood (Suh and Blackwell 2005a, b).

In this study we use both microscopic examination and molecular analysis of gut contents to more precisely characterize the feeding habits and trophic role of 10 rove beetle species common in the boreal forest of Quebec. There are few published data on gut contents, of these species and little is known of their food affiliations, except for some general statements on habitat preferences of Tachinus species (Campbell 1973) and limited observations on hosts and gut contents of some Tachinus and Pseudopsis species (Newton 1984).

\section{Material and methods}

\section{Sampling sites and rove beetle species}

Rove beetles were collected as part of a large field experiment examining the impacts of biomass harvesting on forest ecosystem functioning (Thiffault et al. 2011, Venier et al. 2012) within the Montmorency Teaching and Research Forest (ranges of latitude and longitude: $47^{\circ} 13^{\prime}$ to $47^{\circ} 22^{\prime} \mathrm{N}$, and $71^{\circ} 05^{\prime}$ to $71^{\circ} 11^{\prime} \mathrm{W}$ ) approximately $70 \mathrm{~km}$ north of Quebec City, Quebec, Canada. This site is part of a 60-year-old boreal balsam firwhite birch dominated forest in the Laurentian Mountains. The site and experimental layout were described in detail by Work et al. (2013). All beetles were collected using pitfall traps deployed between June and August 2012. Beetles were collected from both harvested and unharvested stands in $75 \%$ ethanol with some vinegar, and later cleaned 
with $75 \%$ ethanol and mounted on cards (Aleocharinae) or points (e.g., Tachyporinae, Pseudopsinae). We used the 10 most abundant rove beetle species for this study, together constituting $78 \%$ of all rove beetles collected (85-1785 specimens per species): Aleocharinae: Atheta capsularis Klimaszewski, Atheta klagesi Bernhauer, Oxypoda grandipennis (Casey); Tachyporinae: Bryophacis smetanai Campbell, Ischnosoma longicorne (Mäklin), Mycetoporus montanus Luze, Tachinus fumipennis (Say), Tachinus frigidus Erichson, Tachinus quebecensis Robert; and Pseudopsinae: Pseudopsis subulata Herman (Figs 2-11).

\section{Gut extraction for microscopical analysis}

Six dried and mounted specimens of each species were selected from samples collected in 2012. Individual specimens were softened in distilled water and ammonia solution for about 15 minutes and their guts were dissected in distilled water under a stereoscopic microscope. The colon and rectum of the hindgut were transferred directly to absolute alcohol, placed on a glass slide with Canada balsam, and pressed by dissecting needles to liberate gut contents and then covered with a cover slip. Slides were studied under a compound microscope (Reichert, Vienna, Austria) and photographs were taken using an Olympus DP73 digital camera. The following publications were consulted for fungal spore illustrations: Hanlin $(1990,1998)$.

\section{Gut DNA extraction}

DNA from gut contents was extracted from 10 individuals of each species of rove beetle using the QIAamp DNA Micro kit from Qiagen, according to the manufacturer's specifications. Gut contents from the 10 individuals were pooled for DNA extraction. DNA samples were eluted from the columns in $100 \mu \mathrm{L}$ of PCR grade nuclease-free water and the concentration was determined spectrophotometrically by reading absorbance at $260 \mathrm{~nm}$ and $280 \mathrm{~nm}$ with the Synergy Mx microplate reader (BioTek).

\section{PCR amplifications, cloning and sequence analysis}

PCR amplifications were performed using three primers universal to the internal transcribed spacer (ITS) regions of the nuclear ribosomal repeat and used in the following combinations

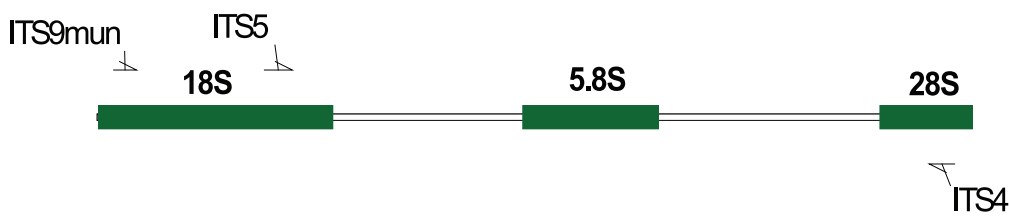

Figure I. Map of ribosomal RNA genes and ITS regions. 


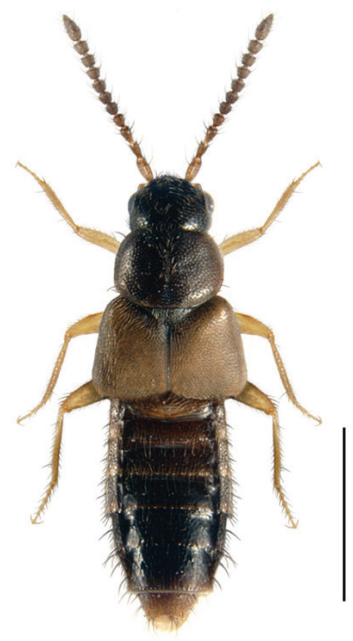

2. Atheta capsularis

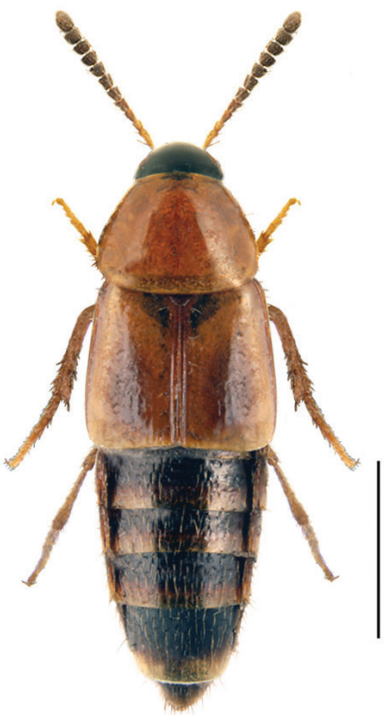

5. Bryophacis smetanai

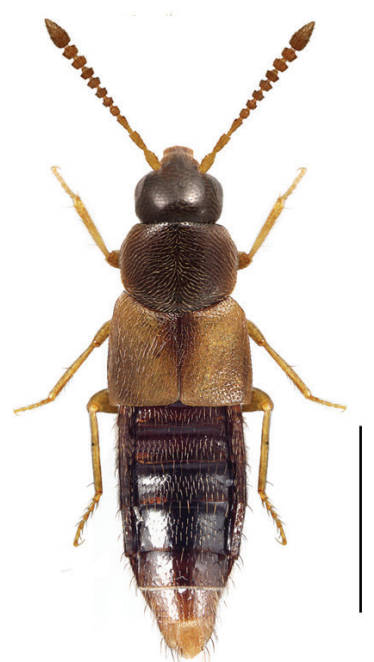

3. Atheta klagesi

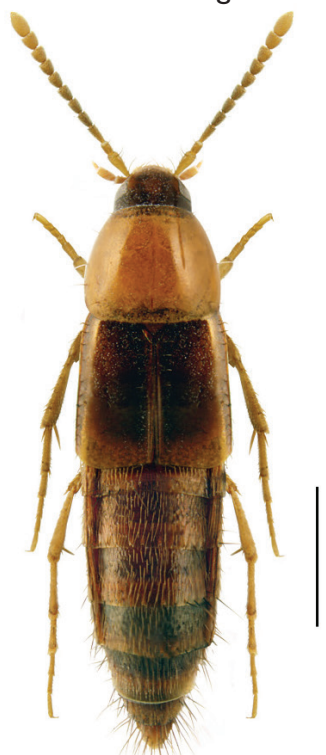

6. Ischnosoma longicorne

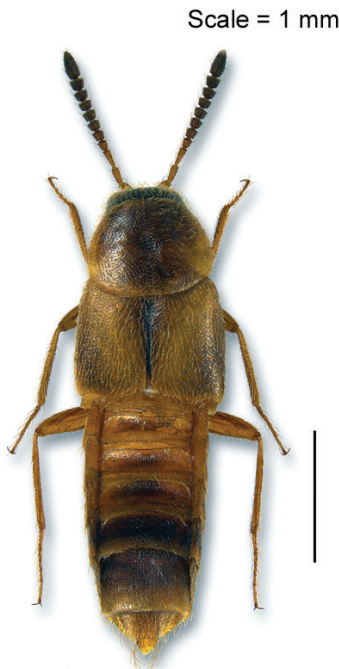

4. Oxypoda grandipennis

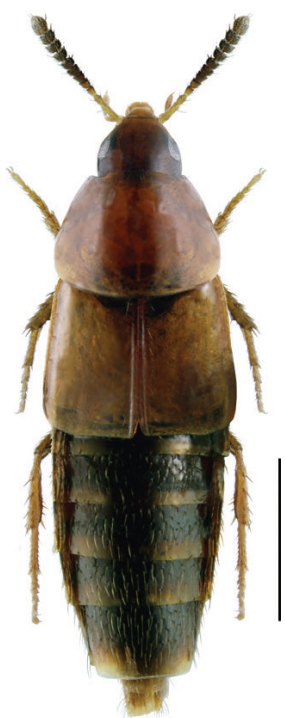

7. Mycetoporus montanus

Figures 2-7. Body images of rove beetles in dorsal view: 2 Atheta capsularis Klimaszewski 3 Atheta klagesi Bernhauer 4 Oxypoda grandipennis (Casey) 5 Bryophacis smetanai Campbell 6 Ischnosoma longicorne (Mäklin) [previously cited as synonymous I. fimbriatum Campbell] 7 Mycetoporus montanus Luze [previously cited as synonymous $M$. rugosus Hatch].

(ITS9mun+ITS4 or ITS5+ITS4). The detailed sequences of the primers are given in Table 1; they specifically amplify a DNA fragment covering the ITS1 region, the 5.8S rRNA gene, and the ITS2 region between the $18 \mathrm{~S}$ and $28 \mathrm{~S}$ rRNA genes (Fig. 1). 
Table I. Primers used in this study.

\begin{tabular}{l|l|l}
\hline Primer name & Primer sequence, 5'-3' $^{\prime}$ & Primer source study \\
\hline ITS9mun & TGTACACACCGCCCGTCG & Egger (1995) \\
\hline ITS5 & GGAAGTAAAAGTCGTAACAAGG & White et al. (1990) \\
\hline ITS4 & TCCTCCGCTTATTGATATGC & White et al. (1990) \\
\hline
\end{tabular}

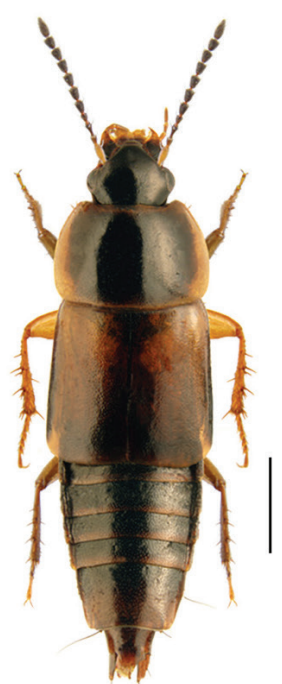

8. Tachinus frigidus

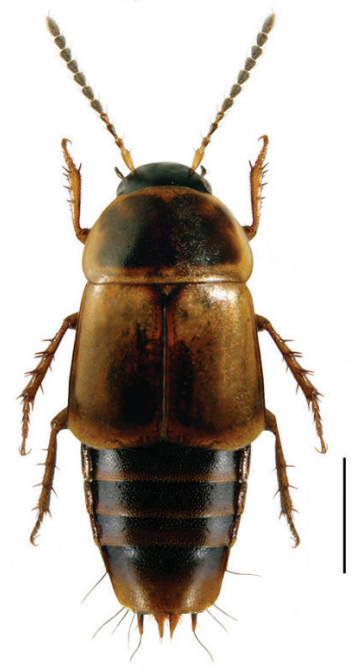

9. Tachinus fumipennis

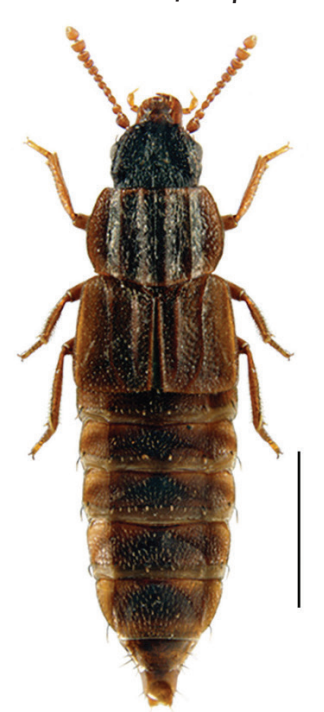

II.Pseudopsis subulata

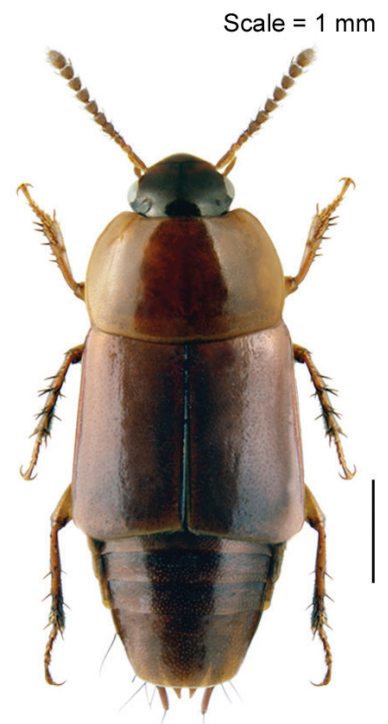

10. Tachinus quebecensis

Figures 8-I I. Body images of rove beetles in dorsal view: 8 Tachinus frigidus Erichson 9 Tachinus fumipennis (Say) 10 Tachinus quebecensis Robert II Pseudopsis subulata Herman. 
Table 2. Distribution of yeast and spores in different rove beetle species from microscopical observation. Subfamilies are: A, Aleocharinae; P, Pseudopsinae; T, Tachyporinae.

\begin{tabular}{|c|c|c|c|c|c|c|c|c|}
\hline \multirow{2}{*}{ Rove beetle species } & \multicolumn{8}{|c|}{ Spore Type } \\
\hline & Yeast & 1 & 2 & 3 & 4 & 5 & 6 & 7 \\
\hline Atheta capsularis (A) & $x$ & & & & & & & \\
\hline Atheta klagesi (A) & $x$ & & & & & & & \\
\hline Oxypoda grandipennis (A) & $x$ & & & & & & & \\
\hline Bryophacis smetanai $(\mathrm{T})$ & $x$ & $x$ & & & & & & \\
\hline Ischnosoma longicorne $(\mathrm{T})$ & $x$ & & $x$ & & & & & \\
\hline Mycetoporus montanus (T) & $x$ & & & $x$ & & & & \\
\hline Tachinus frigidus $(\mathrm{T})$ & $x$ & & & & $x$ & $x$ & $x$ & \\
\hline Tachinus fumipennis $(\mathrm{T})$ & $x$ & & & $x$ & $x$ & $x$ & & \\
\hline Tachinus quebecensis $(\mathrm{T})$ & $x$ & & & & & & & $x$ \\
\hline Pseudopsis subulata $(\mathrm{P})$ & $x$ & & & & & & & \\
\hline
\end{tabular}

The PCR reactions contained 30 ng of DNA, 2X HotStarTaq Plus Master Mix from Qiagen, which contains one unit of HotStarTaq Plus DNA Polymerase, PCR Buffer with $1.5 \mathrm{mM} \mathrm{MgCl}, 200 \mu \mathrm{M}$ of each dNTP and $0.3 \mu \mathrm{M}$ of each primer in a $30 \mu \mathrm{L}$ final reaction. PCR amplification was carried out using an initial denaturation step at $95^{\circ} \mathrm{C}$ for $15 \mathrm{~min}$, followed by 35 cycles: $15 \mathrm{~s}$ at $95^{\circ} \mathrm{C}, 30$ s at $52^{\circ} \mathrm{C}, 30$ s at $72^{\circ} \mathrm{C}$, and a final extension for $10 \mathrm{~min}$ at $72^{\circ} \mathrm{C}$. Cycling was performed on a PTC200 Peltier Thermal Cycler (MJ Research). Amplified fragments were inserted directly in the TA cloning vector (Invitrogen) and transformed into E. coli strain DH10B. Plasmids were isolated using the Qiacube with the Qiagen miniprep columns (Qiagen) and sequenced with an ABI 3730xl Data Analyzer (Applied Biosystems). After removing the DNA cloning vector segments, the remaining sequences were compared with reference sequences contained in the GenBank nucleotide sequence database using the BLAST algorithm (Altschul et al. 1990) and in the MycoBank database search engine (Robert et al. 2005) to find the closest matching sequences. A total of 228 clones were sequenced in this study.

\section{Results}

\section{Microscopic observations}

We observed no cuticle characteristic of arthropods in the guts of any dissected individuals. The only identifiable material was yeasts and fungal spores. Through microscopic observation of spore morphology, we were unable to discriminate among the yeast species, so these were recorded simply as "yeasts" (Figs 12-18, 20, 30, 32, 34, 35). However, at least seven different spore types could be discriminated using microscopic techniques and available taxonomic resources, although they could not be identified with certainty (Figs 


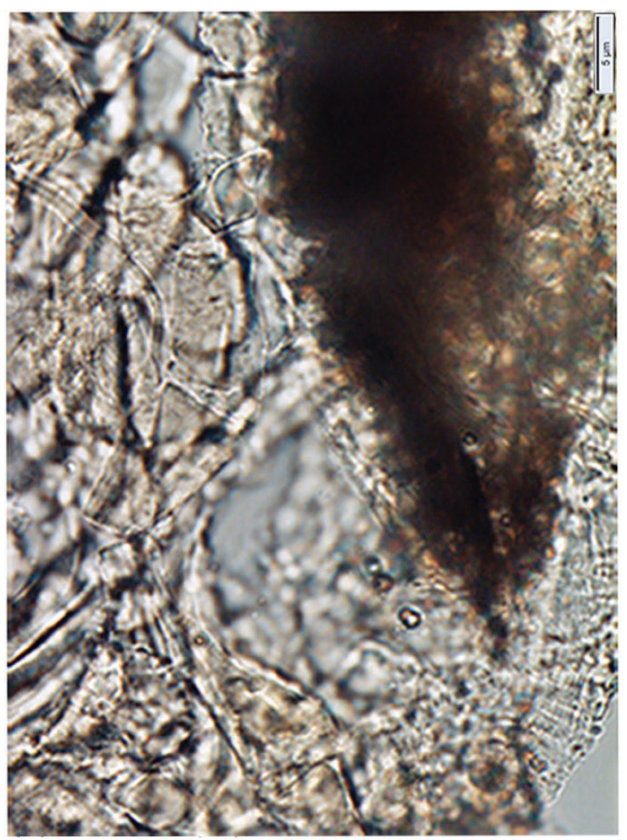

12. Atheta capsularis

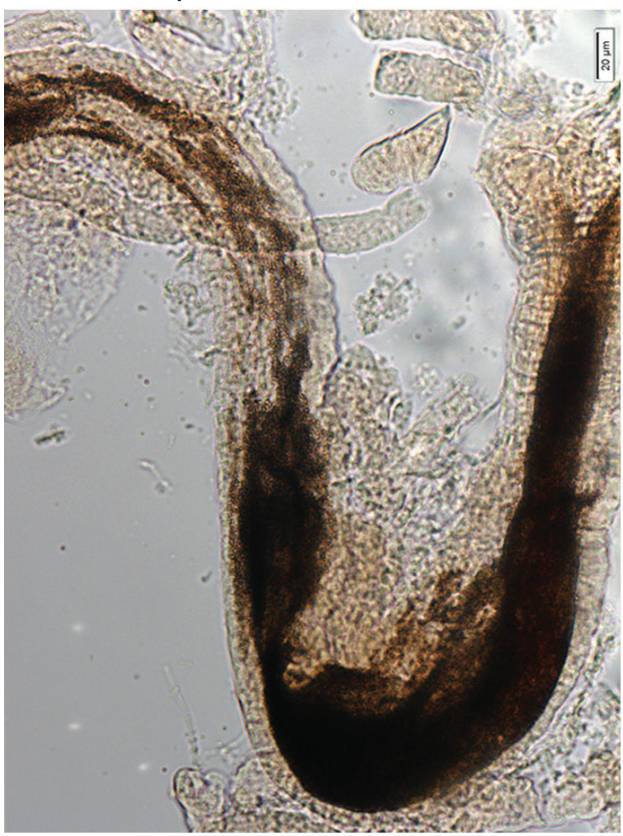

14. Atheta klagesi

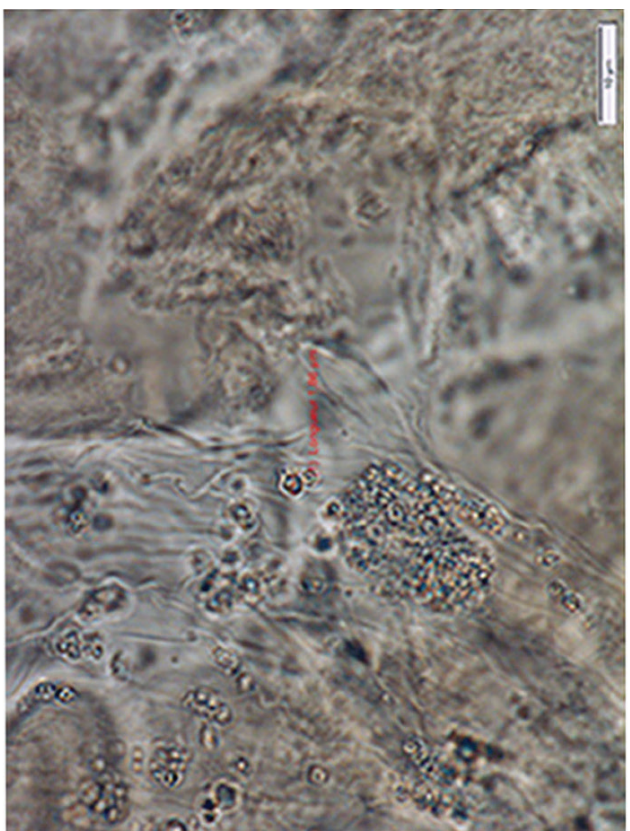

13. A. capsularis

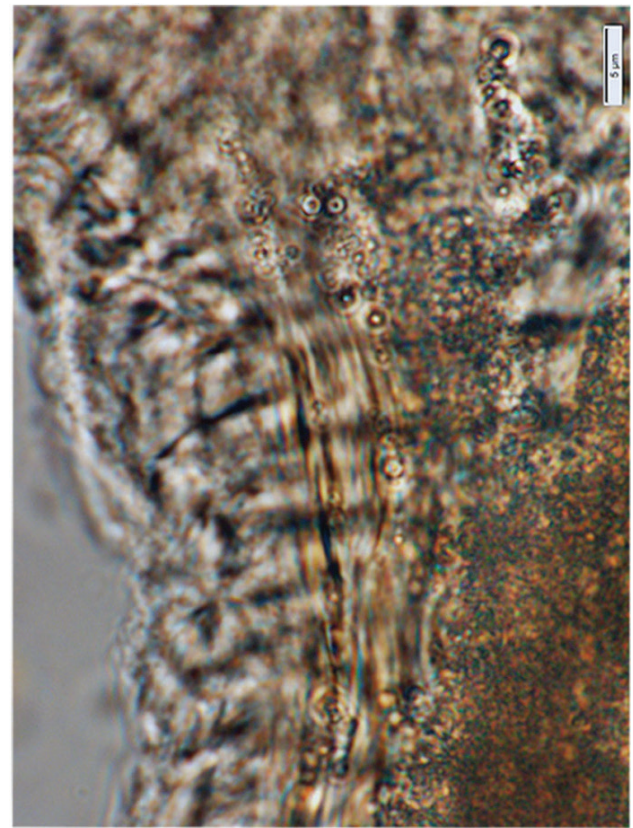

I5. A. klagesi

Figures 12-15. Images of hindgut content of the following rove beetle species: 1 2-13 Atheta capsularis Klimaszewski I4-I5 Atheta klagesi Bernhauer. 


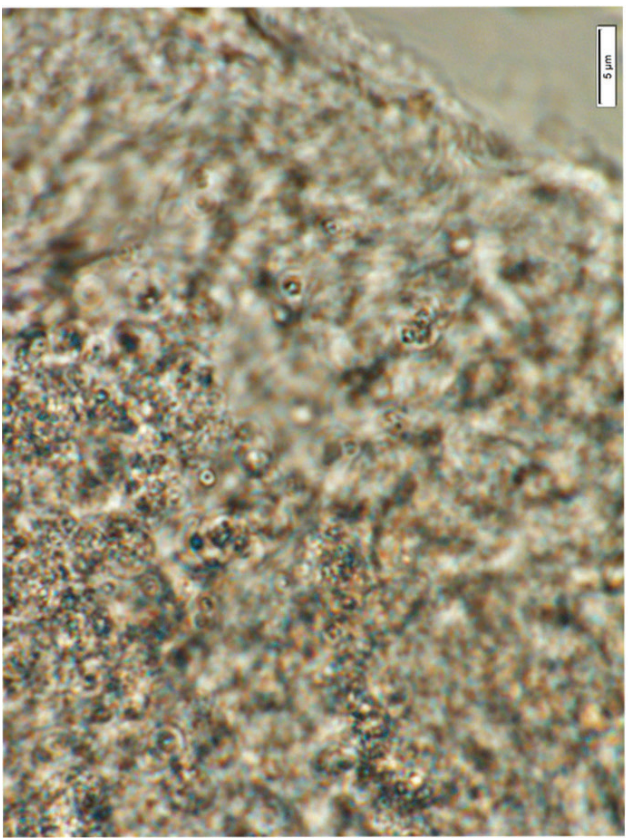

16. Oxypoda grandipennis

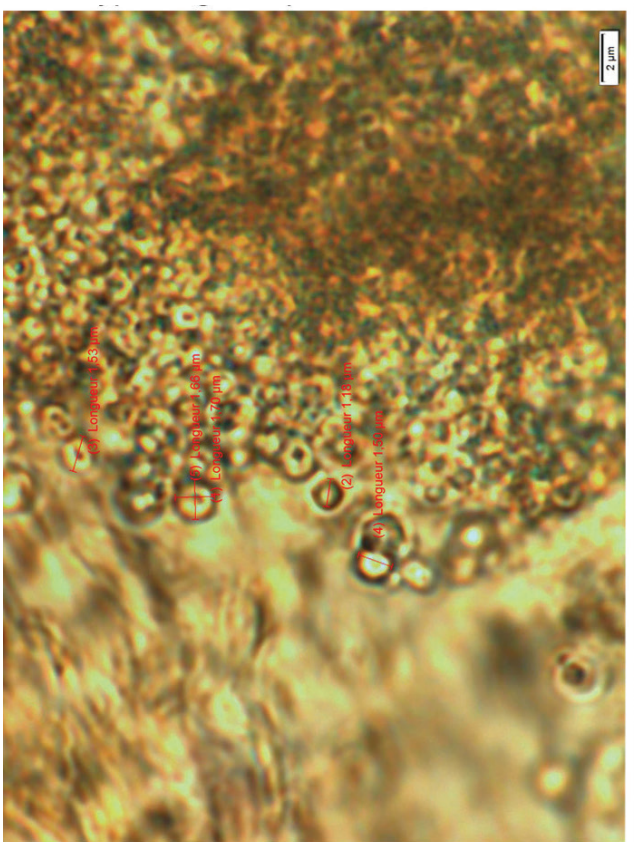

I8. B. smetanai

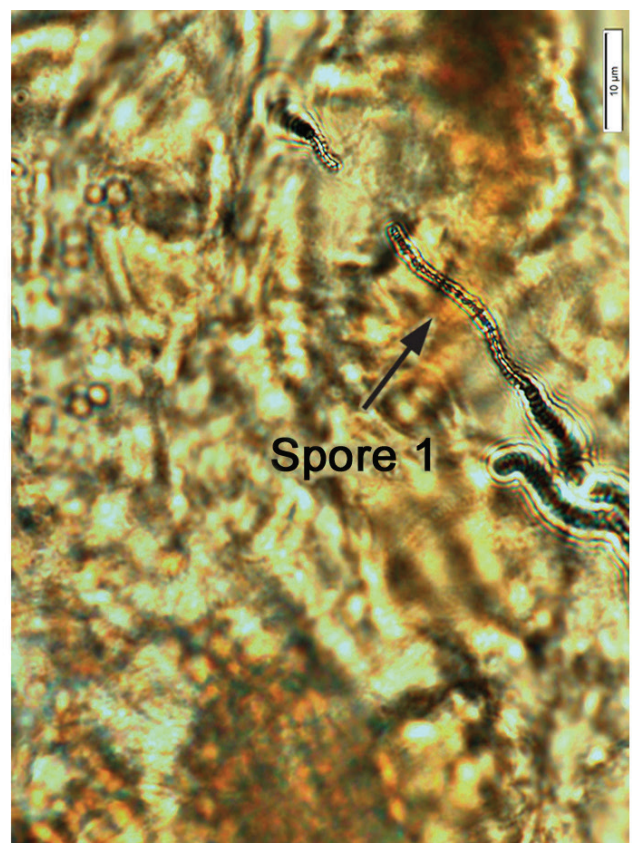

17. Bryophacis smetanai

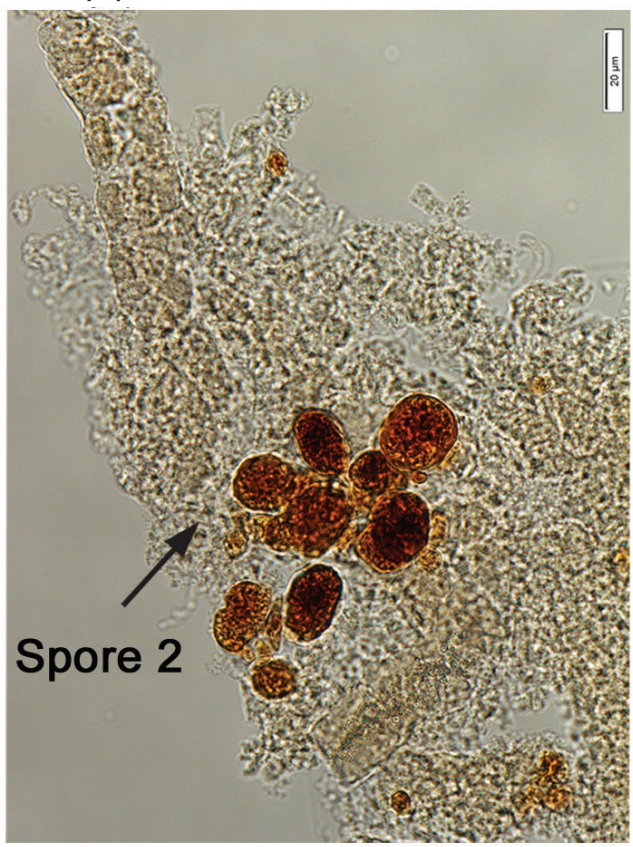

19. Ischnosoma longcorne

Figures 16-19. Images of hindgut content of the following rove beetle species: 16 Oxypoda grandipennis (Casey) I 7-I8 Bryophacis smetanai Campbell I 9 Ischnosoma longicorne (Mäklin). 


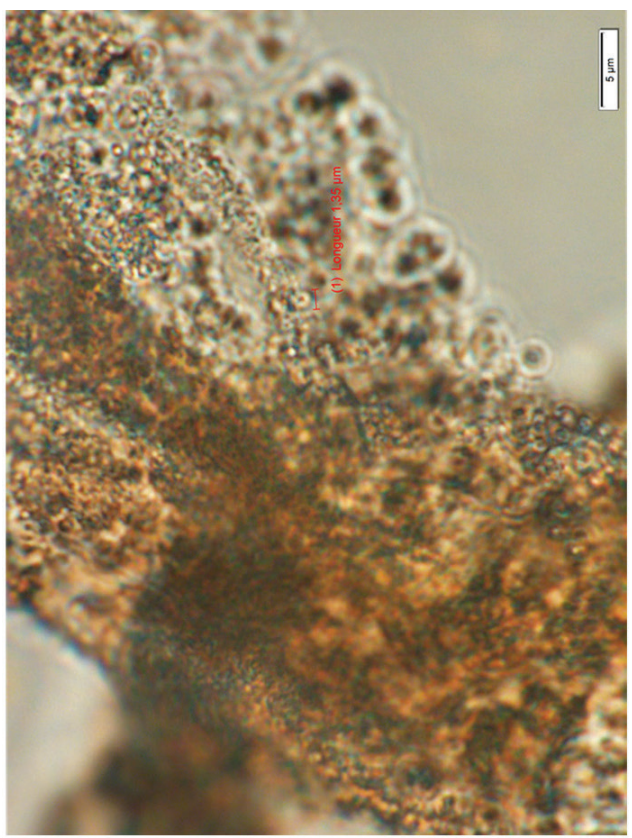

20. I. longcorne

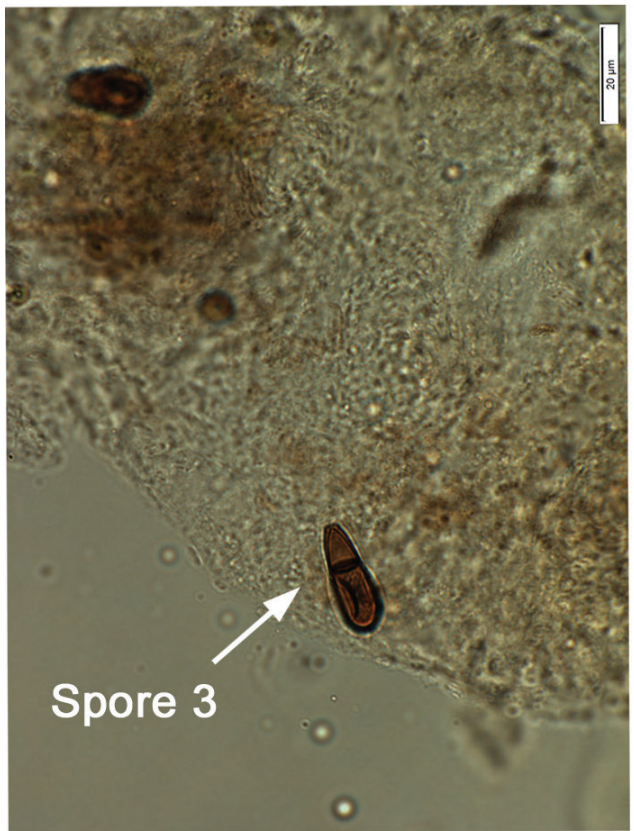

22. M. montanus

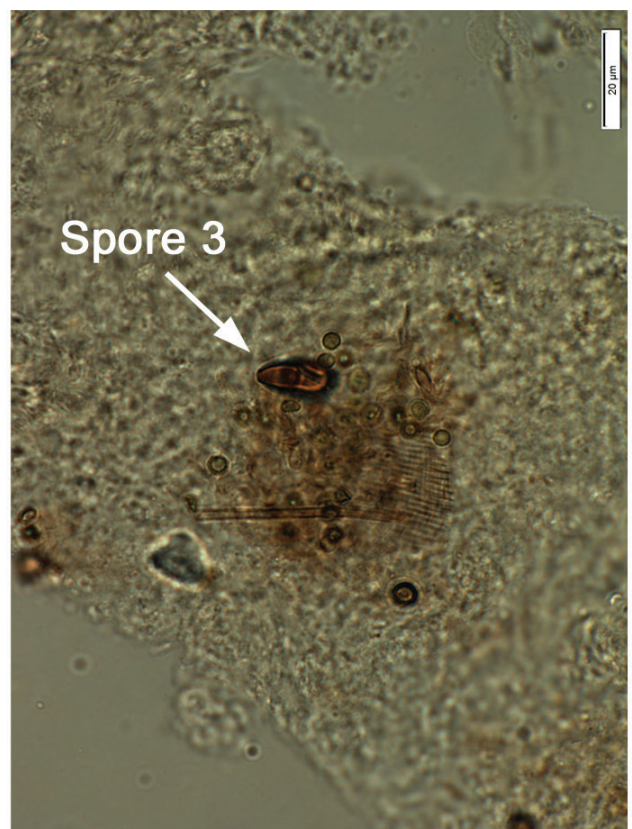

21. Mycetoporus montanus

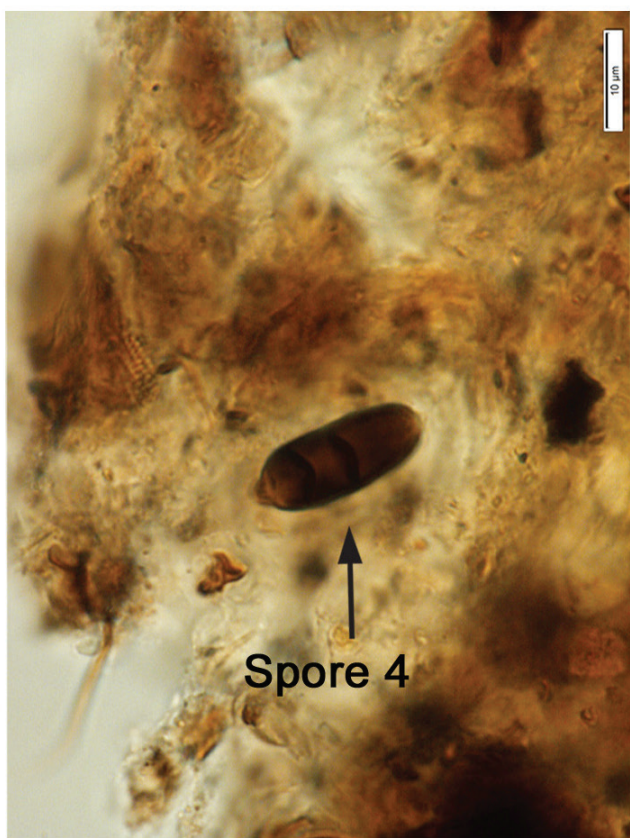

23. Tachinus frigidus

Figures 20-23. Images of hindgut content of the following rove beetle species: $\mathbf{2 0}$ Ischnosoma longicorne (Mäklin) 21-22 Mycetoporus montanus Luze 23 Tachinus frigidus Erichson. 

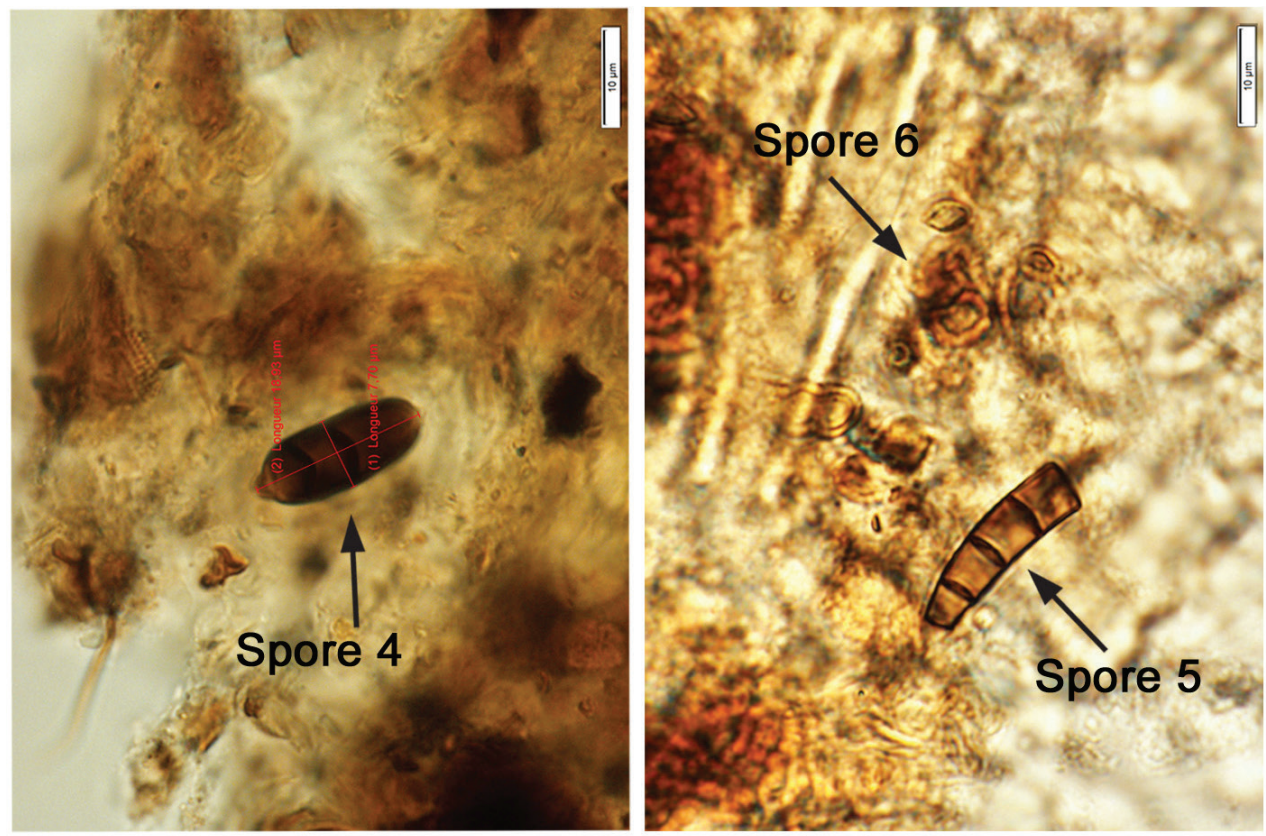

\section{T. frigidus}

\section{T. frigidus}
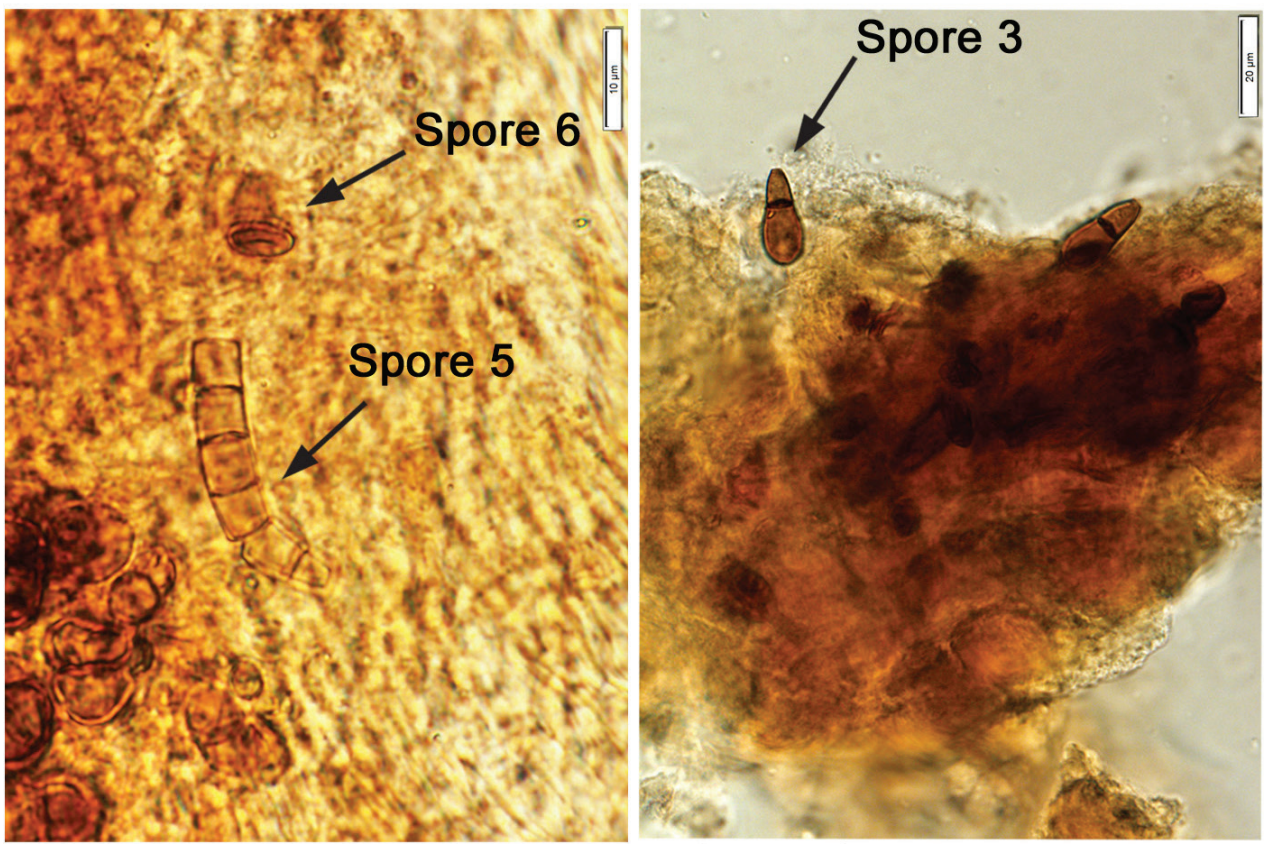

\section{T. frigidus}

\section{Tachinus fumipennis}

Figures 24-27. Images of hindgut content of the following rove beetle species: 24-26 Tachinus frigidus Erichson $\mathbf{2 7}$ Tachinus fumipennis (Say). 


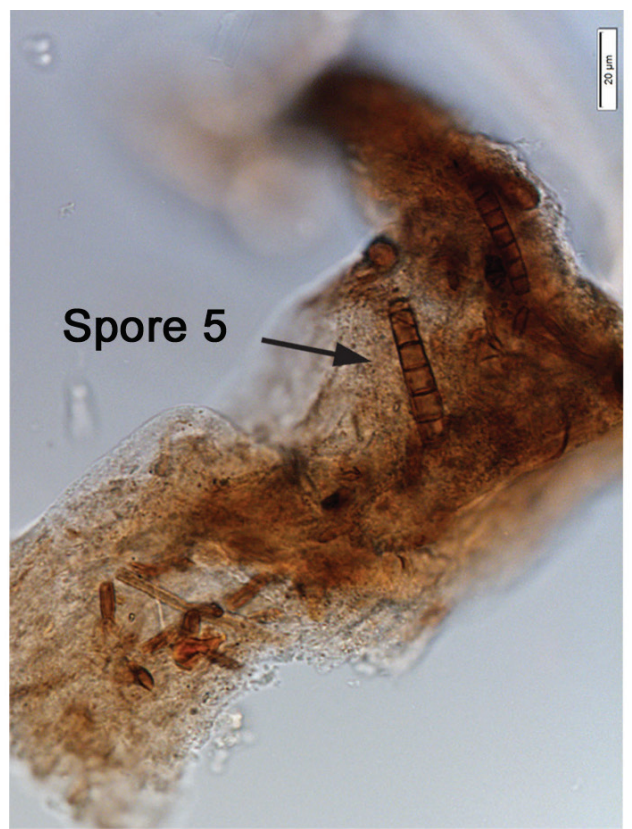

28. T. fumipennis

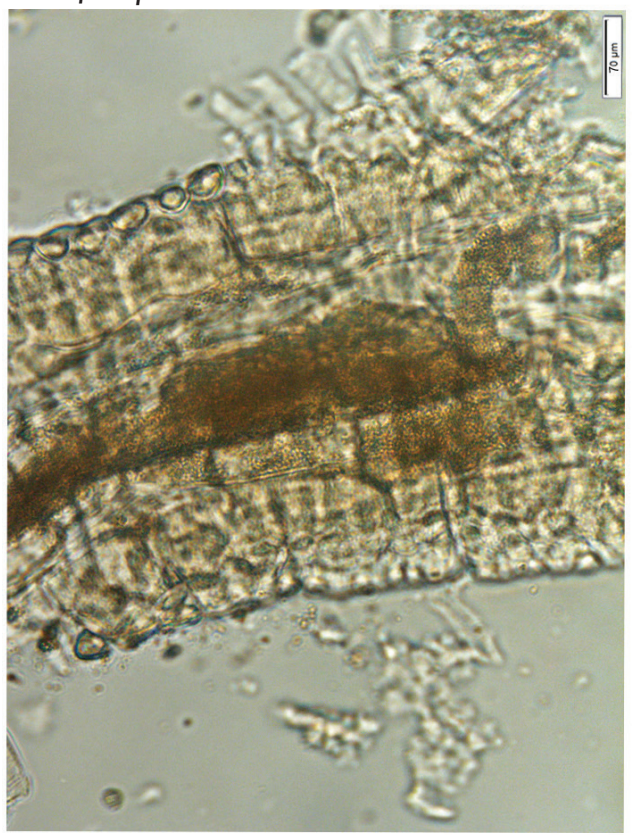

30. T. fumipennis

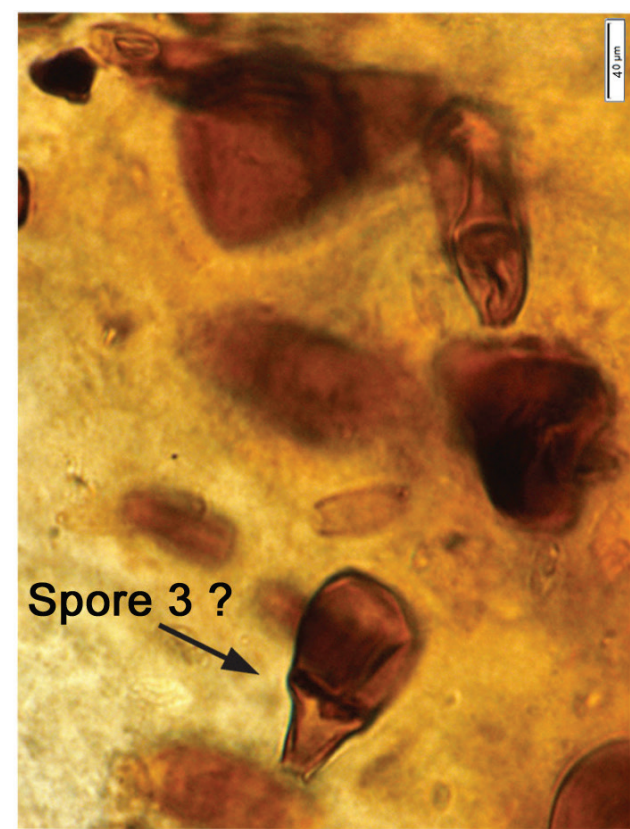

29. T. fumipennis

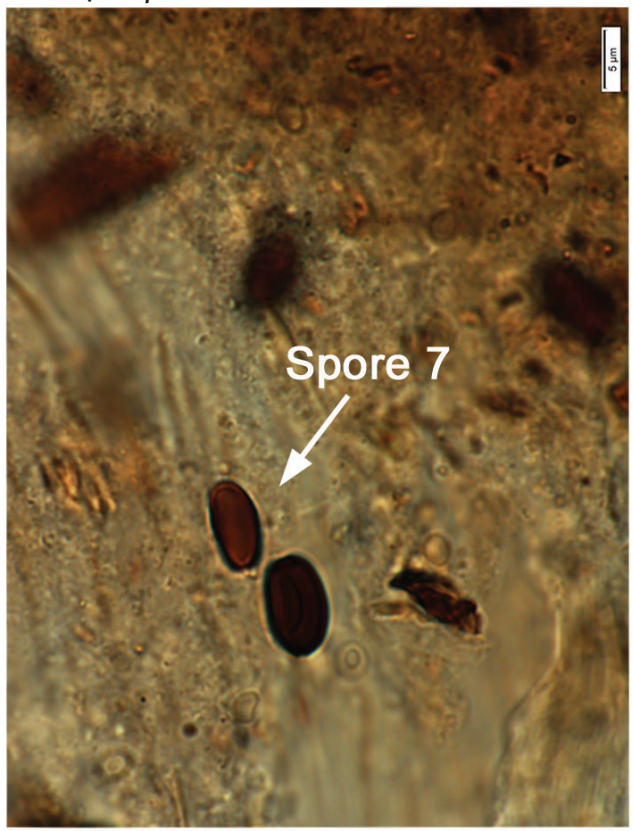

31. Tachinus quebecensis

Figures 28-3 I. Images of hindgut content of the following rove beetle species: 28-30 Tachinus fumipennis (Say) 31 Tachinus quebecensis Robert. 

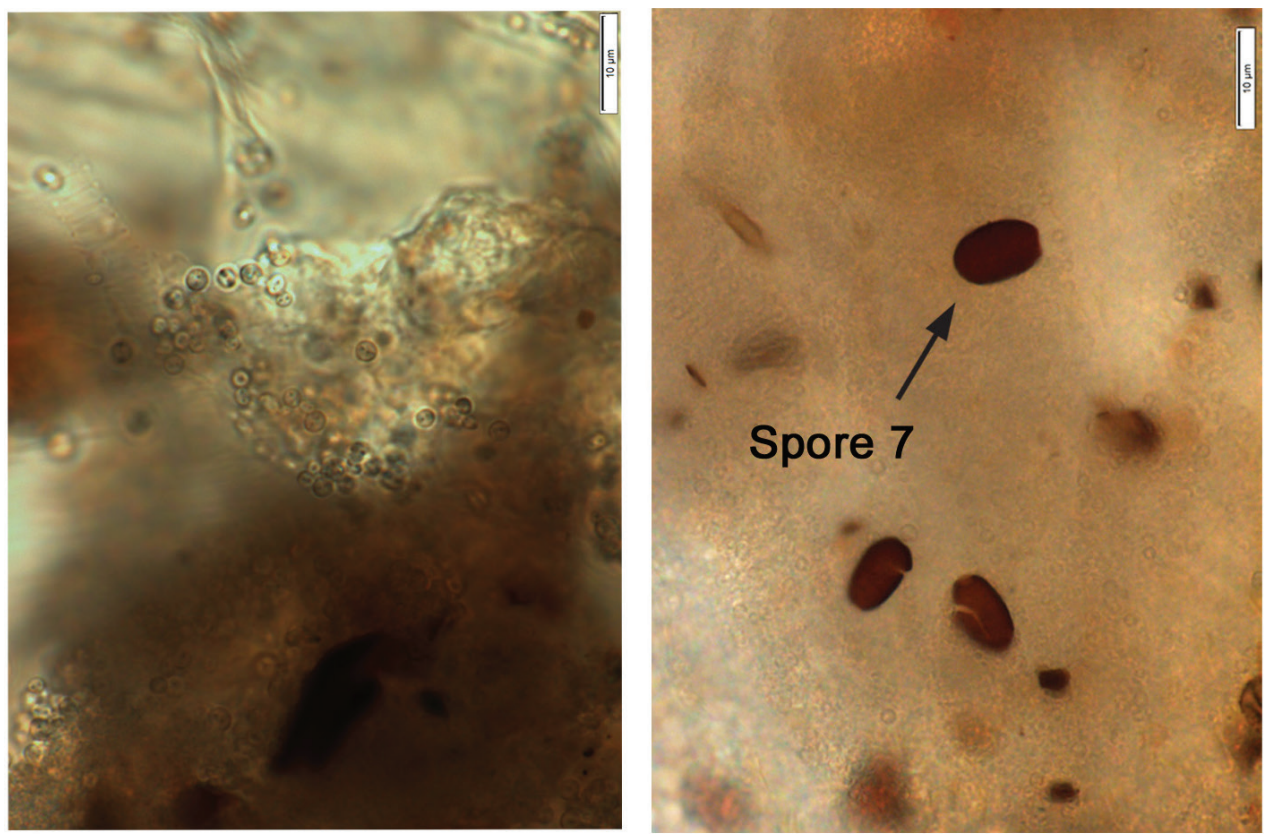

32. T. quebecensis

33. T. quebecensis
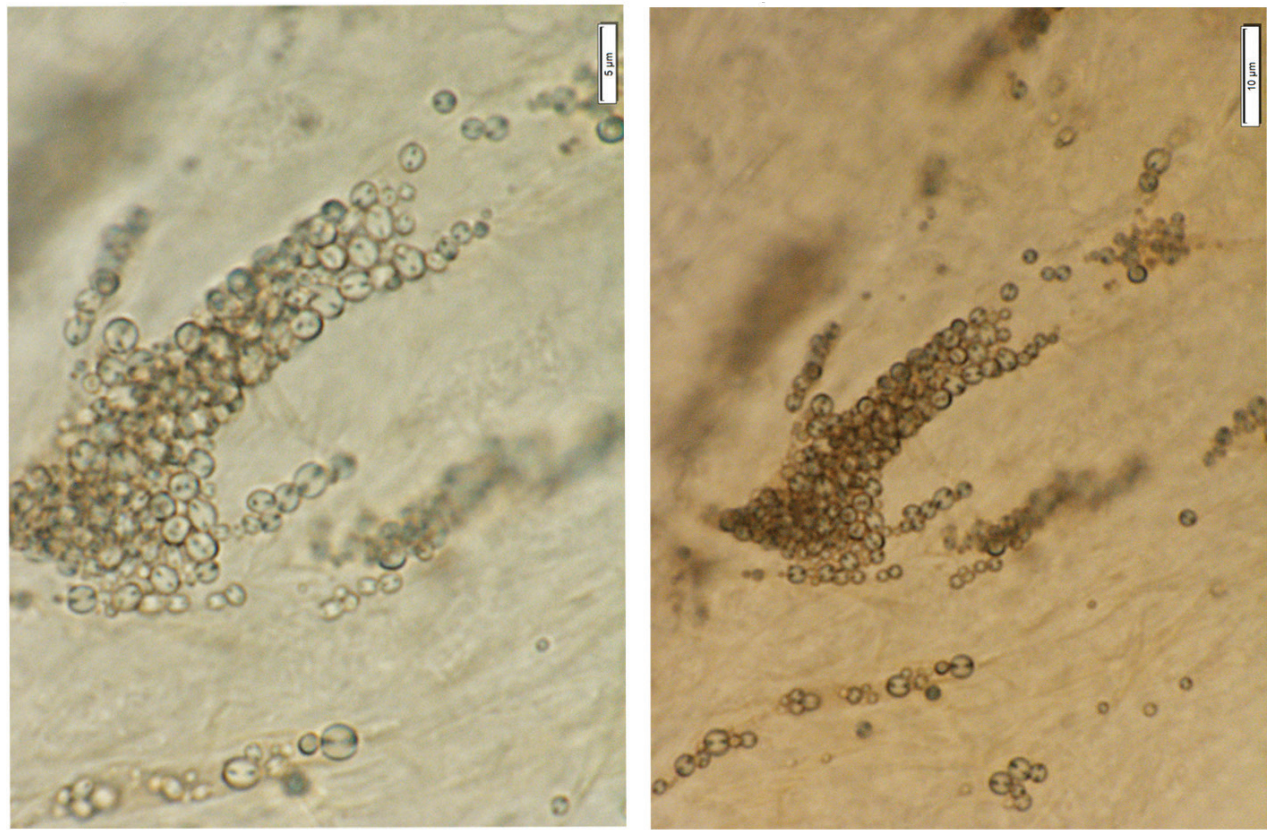

34. Pseudopsis subulata

35. P. subulata

Figures 32-35. Images of hindgut content of the following rove beetle species: 32-33 Tachinus quebecensis Robert 34-35 Pseudopsis subulata Herman. 
17 [spore type 1]; 19 [spore type 2]; 21, 22, 27, 29? [spore type 3]; 23, 24 [spore type 4]; 25, 26, 28 [spore types 5 and/or 6]; and 31, 33 [spore type 7]). Some of these spores are of the following morphology: (long arthrospore fragment, Fig. 17); immature ascomycete cleistothecia or pycnidia, (Fig. 19, spore \# 2); and dark walled spores (Figs 31, 33, spore \# 7; dark coloured spores, Figs 23, 24, spore \# 4). All 10 rove beetle species had yeasts in their hindgut, but spores were found only in the six tachyporine species and were missing in Aleocharinae and Pseudopsinae (Table 2). Yeasts were densely packed in Aleocharinae and Pseudopsinae and less so in remaining species. Spore types 1, 2, 6, and 7 were each found in a single species, while types 3, 4, and 5 were found in Tachinus fumipennis and either T. frigidus or Mycetoporus montanus (Table 2). These two species of Tachinus had the most diverse spore diets (three types each).

\section{Molecular analyses}

In total, we obtained 186 fungal and bacterial sequences from the 10 species of rove beetles, ranging from 19-33 sequences per species (Table 3). Of these, 134 (72\%) could be identified to genus, species, or unnamed clones with high certainty $(>90 \%$ sequence match) by comparison to sequences in the GenBank and MycoBank databases. Twenty-nine sequences ( 2 fungal and all 27 bacterial) showed lower levels of sequence similarity (78-90\%). We could not match 23 sequences (a range of 0 to $24 \%$ unmatched sequences per species, see Table 3).

In all, we identified 17 fungal taxa in the phyla Ascomycota and Basidiomycota and two bacterial taxa in the phylum Proteobacteria through molecular analysis (Table $3)$. The number of taxa distinguished from each staphylinid species varied from one in $O$. grandipennis and B. smetanai to eight in T. quebecensis, and averaged 3.3 per species (Table 3). We found yeasts in all of the 10 beetle species studied, with Candida mesenterica (Geiger) Diddens \& Lodder accounting for 92 sequences and occurring in 9 of the 10 beetle species. The next most commonly identified taxon was the bacterial species Serratia marcescens Bizio, which accounted for 24 sequences found in five beetle species. The vast majority of taxa in beetle guts were found in just one (13 taxa) or two (1 taxon) sequences.

\section{Discussion}

Both dissection and molecular analysis of guts strongly suggest that rove beetles in this study may feed primarily on yeasts. Yeasts are ubiquitous (in soil, on decaying plant material including deadwood, and on berries) and they are an important part of the diet of at least some fungivorous beetle species (Suh and Blackwell 2005b). Some species of Candida yeasts have close associations with saproxylic insects and are capable of transforming d-xylose and other important components of lignocellulose to ethanol (Wang et al. 2005). However, yeasts within the $C$. mesenterica clade are associated with 
Table 3. Number and identity of genetic sequences extracted from the gut contents of 10 species of Staphylinidae. Accession numbers in brackets follow species name in the first column.

\begin{tabular}{|c|c|c|c|c|c|c|c|c|c|c|c|}
\hline Specific taxon & 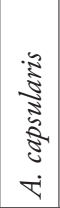 & 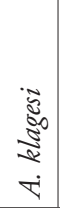 & 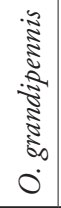 & 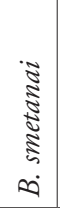 & 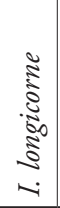 & 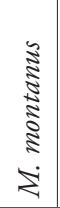 & 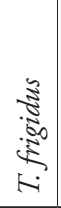 & 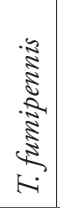 & 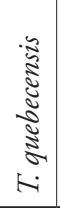 & 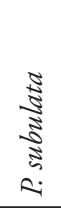 & Total \\
\hline \multicolumn{12}{|l|}{ Fungi } \\
\hline Acremonium psammosporum (GU566287) & & & & & $2^{\mathrm{a}}$ & & & & & & $2^{\mathrm{a}}$ \\
\hline Alternaria sp. (GU584946) & 1 & & & & & & & & & & 1 \\
\hline Aspergillus amstelodami (HQ728257) & 1 & & & & & & & & & & 1 \\
\hline Aspergillus versicolor (AJ937750) & & & & & & & & & & 1 & 1 \\
\hline Candida cretensis (HF558653) & 1 & & & & & 1 & 16 & & & & 18 \\
\hline Candida mesenterica (FM178362) & 12 & 8 & 12 & 14 & 5 & 9 & 4 & 20 & 8 & & 92 \\
\hline Candida sophiae-reginae (HQ652073) & & & & & & & & & 1 & & 1 \\
\hline Candida railenensis (JX455763) & & & & & & 1 & & & & & 1 \\
\hline Candida sp. (AY498864) & & & & & & & 1 & & & & 1 \\
\hline Cladosporium tassiana ( AF393706) & & & & & & & & & & 1 & 1 \\
\hline Cryptococcus (uncultured) (KC753404) & & 1 & & & 2 & & & & 1 & & 4 \\
\hline Hypocreales sp. TR114 (HQ608125) & & & & & 1 & & & & & & 1 \\
\hline Penicillium spinulosum (GU566252) & & & & & 1 & & & & & & 1 \\
\hline Pichia delftensis (AY923246) & & & & & & & & 1 & & & 1 \\
\hline Pichia misumaiensis (U73581) & & & & & & & & & 1 & & 1 \\
\hline Pichia membranifaciens (JQ26345) & & & & & & & & & 1 & & 1 \\
\hline Rhodotorula mucilaginosa (HQ702343) & & & & & & & & & 1 & & 1 \\
\hline $\begin{array}{l}\text { Uncultured fungus clone 50-p12-A5 } \\
\text { (HQ267068) }\end{array}$ & & 2 & & & & & & & 5 & & 7 \\
\hline \multicolumn{12}{|l|}{ Insects } \\
\hline Ten species from this study & & 6 & 8 & 1 & 5 & 10 & & & & 7 & 37 \\
\hline \multicolumn{12}{|l|}{ Bacteria } \\
\hline Bradyrhizobium japonicum (BA000040) & & & & $1^{\mathrm{b}}$ & $2^{\mathrm{b}}$ & & & & & & $3^{\mathrm{b}}$ \\
\hline Serratia marcescens (CР003942) & & & & $4^{\mathrm{b}}$ & & & $1^{\mathrm{b}}$ & $1^{\mathrm{b}}$ & $2^{\mathrm{b}}$ & $16^{\mathrm{b}}$ & $24^{\mathrm{b}}$ \\
\hline Unmatched sequences & 4 & 3 & 1 & 2 & 1 & 1 & 3 & 0 & 0 & 8 & 23 \\
\hline Total & 19 & 20 & 21 & 22 & 19 & 22 & 25 & 22 & 20 & 33 & 223 \\
\hline
\end{tabular}

a Sequences with 86 to $90 \%$ sequence similarity.

b Sequences with 78 to $85 \%$ sequence similarity.

many insect groups and are likely indicative of habitat associations rather than being highly specific gut symbionts (Suh and Blackwell 2005a). Yeasts in the C. mesenterica clade, particularly species in its subclade $\mathrm{A}$, are known to be associated with fungal basidiocarps and have previously been isolated from the digestive tracts and body surfaces of six families of basidiocarp-inhabiting beetles, including one unidentified species of Staphylinidae (Suh and Blackwell 2005a). 
With the exception of the relatively broad consumption of $C$. mesenterica yeasts by most species, finer patterns in feeding preferences among rove beetles were difficult to assess. This was partly a result of the limited number of matched sequences for some species, which in turn probably reflects in part the limits of available reference sequences. The limited numbers of sequences obtained in our study could be related to degradation of DNA as the result of suboptimal preservation medium.

The prevalence of other fungi in addition to yeasts and the presence of spores in rove beetle guts was not unexpected, as many rove beetle species are associated with fungi (Campbell 1973, Newton 1984, Newton et al. 2000, Thayer 2005). Spores of at least seven species of fungi were found in the guts of six of the rove beetle species, although it is not known whether the beetles derive nutrition from spores. Many spores have tough walls that enable them to pass through digestive tracts; however, others are certainly digested and some are cracked by the mouthparts to provide nutrition for beetles specializing in spore feeding (Lawrence 1989, Betz et al. 2003). It cannot be determined from available data whether the ingestion of spores by these rove beetles is incidental or intentional. However, the absence of spores in four species, including all three species of Aleocharinae, is notable and raises the question of whether some species do not ingest spores, either because they are unable to, or because they have difficulty finding them in a particular microhabitat.

Although we isolated bacteria less commonly than fungi, we did find them in six beetle species. The second most commonly detected sequence, in fact, was from the bacterium $S$. marcescens, which is associated with soils; it may sometimes be pathogenic to insects (Flyg et al. 1980). This species of bacteria is probably not an important food source for rove beetles. It may simply be so common in the soil that incidental ingestion is frequent. The other species of bacterium we isolated, B. japonicum, is a soildwelling, nitrogen-fixing species associated with legume plants (Rivas et al. 2009), so seems unlikely to be a food source for rove beetles.

It is notable that no arthropod cuticle or evidence of animal DNA sequences were found in the guts of any of these species despite the fact that predation on arthropods (especially mites, springtails, and smaller insects) is common in the family (Newton et al. 2000, Thayer 2005). Two possible interpretations are that: (1) the adults of these species are entirely fungivorous, or (2) they are predaceous and use preoral digestion, as many staphylinids do (e.g., Evans 1965, Dennison and Hodkinson 1983, Thayer 2005) and specifically as has been hypothesized for Pseudopsis (Pseudopsinae) and the entire group of subfamilies to which it belongs (Grebennikov and Newton 2009). The fact that these 10 species represent seven genera and three subfamilies suggests that analysis of gut contents of many more species is needed to provide a better sampling of rove beetle diets. Identification of the many presently unmatched DNA sequences, which could include animal DNA, and ruling out of preoral digestion are also required before carnivory can be excluded with certainty for the species studied here.

In work conducted to characterize rove beetle responses to removal of logging residues following clearcut harvesting in boreal balsam fir forests of Quebec (Work et al. 
2013; Klimaszewski, unpublished data), several response patterns were shown by different species. Seven species (A. capsularis, A. klagesi, B. smetanai, O. grandipennis, T. frigidus, T. fumipennis and T. quebecensis) were found predominantly or exclusively in uncut forest rather than forest subjected to harvesting treatments. Except for T. quebecensis, all of these may feed partly or wholly on basidiocarps, as the predominance of basidiocarpassociated Candida spp. in their guts suggests. These species may not persist well in harvested stands because their drier, disturbed conditions are generally far less favourable to mushroom and other sporocarp production (Langor, personal observation). Tachinus quebecensis was found only in uncut stands, and had Candida sophiae-reginae and C. mesenterica isolated from guts in the present study. However, this beetle species had the highest diversity of ingested fungal species, five of them unique to it, and possibly one or more of these represent important food sources that are absent (or rare) in harvested stands, although it is also possible that it is predaceous and all fungi are incidental.

Pseudopsis subulata was the most common species to show a strong affinity for disturbed stands, specifically stands subjected to whole tree harvesting, although it was also found in uncut stands and in stands subjected to harvesting with debris left behind (Work et al. 2013). Interestingly, this is the only rove beetle species that did not have Candida spp. in its gut; however, its gut was typically packed with other yeasts that could not be identified. Perhaps these yeasts have a strong association with disturbed and open habitats.

Mycetoporus montanus was not collected during the first year of the study (Work et al. 2013), but it was common during the second year, when it was collected almost exclusively in harvested treatments (Klimaszewski, unpublished data). It appears that this species moved into disturbed stands and multiplied rapidly, taking advantage of food or breeding sites that became more available in such stands. Although $M$. montanus had $C$. mesenterica in its gut, it also had a large variety of other organisms that could not be identified, some of which may be the primary food source for this species.

Ischnosoma longicorne was commonly found in both uncut and disturbed stands (Work et al. 2013). This species had a high diversity of species in its gut (six fungal and one bacterium species), which may indicate a broad diet and, therefore, a capacity to succeed in many habitat types.

Feeding associations between rove beetles and yeasts provide some insight into potential mechanisms by which biomass harvesting may impact rove beetles. Our results may suggest that dominant rove beetles are feeding on yeasts and other fungi that may or may not be directly associated with sporocarps growing on deadwood substrates. It is important to understand the complexity of factors linking the studied beetles to biomass removal treatments. The removal of additional forest biomass may be affecting beetles not only via potential food linkages, but also by other non-trophic mechanisms such as changes in physical conditions following the removal of the forest overstory (Work et al. 2013).

In addition to characterizing food sources for some abundant species of rove beetles, many of which are good ecological indicators, our work provides some possible explanations for beetle response patterns in the wake of forest disturbance. The relatively easy application of DNA sequencing to gut contents and the steadily increasing wealth of sequence data available to serve as an identification resource means that these 
techniques can now be readily applied in disturbance ecology research to investigate species response patterns and habitat preferences. We encourage broader use of this approach to support future work.

\section{Acknowledgements}

We are grateful to the following individuals for contributing to our research: M. Blais, G. Laflamme, P. DesRochers, and J. Bérubé (Laurentian Forestry Centre - LFC) for useful advice and reference recommendations; S. Dagnault and J. Morissette (LFC) for their help with site preparation, and casual employees R. Batista (Montreal) and A. Gilbert (Québec) for helping with site preparation and collecting and processing insect samples at the Montmorency Experimental Forest. Julie Bouliane and Patrick Pineault of Université Laval, Quebec, helped us with the logistics, site preparation and helpful advice. Pamela Cheers and Isabelle Lamarre (LFC) edited the manuscript and prepared it for publication.

\section{References}

Altschul SF, Gish W, Miller W, Myers EW, Lipman DJ (1990) Basic local alignment search tool. Journal of Molecular Biology 215: 403-410.

Ashe JS (1984) Generic revision of the subtribe Gyrophaenina (Coleoptera: Staphylinidae: Aleocharinae) with review of the described subgenera and major features of evolution. Quaestiones Entomologicae 20: 129-349.

Betz O, Thayer MK, Newton AF (2003) Comparative morphology and evolutionary pathways of the mouthparts in spore-feeding Staphylinoidea (Coleoptera). Acta Zoologica 84: 179238. doi: 10.1046/j.1463-6395.2003.00147.x

Boháč J (1990) The use of staphylinid communities (Coleoptera, Staphylinidae) for the bioindication of the environment quality. Entomologické Problémy 20: 251-258. [In Czech, with English summary]

Boháč J (1999) Staphylinid beetles as bioindicators. Agriculture, Ecosystems and Environment 74: 357-372. doi: 10.1016/S0167-8809(99)00043-2

Campbell JM (1973) A revision of the genus Tachinus (Coleoptera: Staphylinidae) of North and Central North America. Memoirs of the Entomological Society of Canada 90: 1-137. doi: 10.4039/entm10590fv

Crous PW, Gams W, Stalpers JA, Robert V, Stegehuis G (2004) MycoBank: an online initiative to launch mycology into the 21st century. Studies in Mycology 50: 19-22.

Dennison DF, Hodkinson ID (1983) Structure of the predatory beetle community in a woodland soil ecosystem. I. Prey selection. Pedobiologia 25: 109-115.

Egger KN (1995) Molecular analysis of ectomycorrhizal fungal communities. Canadian Journal of Botany 73: 1415-1422.

Evans MEG (1965) A comparative account of the feeding methods of the beetles Nebria brevicollis (F.) (Carabidae) and Philonthus decorus (Grav.) (Staphylinidae). Transactions of the Royal Society of Edinburgh 66: 91-109. doi: 10.1017/S0080456800023395 
Flyg C, Kenne K, Boman HG (1980) Insect pathogenic properties of Serratia marcescens: phage-resistant mutants with a decreased resistance to Cecropia immunity and a decreased virulence to Drosophila. Journal of General Microbiology 120: 173-181.

Grebennikov VV, Newton AF (2009) Good-bye Scydmaenidae, or why the ant-like stone beetles should become megadiverse Staphylinidae sensu latissimo (Coleoptera). European Journal of Entomology 106: 275-301.

Hanlin RT (1990) Illustrated genera of Ascomycetes. APS Press, The American Phytopathological Society, St. Paul, MN, 258 pp.

Hanlin RT (1998) Illustrated genera of Ascomycetes. II. APS Press, The American Phytopathological Society, St. Paul, MN, 261 pp.

Harper GL, King RA, Dodd CS, Harwood JD, Bruford MW, Symondson WOC (2005) Rapid screening of invertebrate predators for multiple prey DNA targets. Molecular Ecology 14: 819-827. doi: 10.1111/j.1365-294X.2005.02442.x

Klimaszewski J (1984) A revision of the genus Aleochara Gravenhorst of America north of Mexico (Coleoptera: Staphylinidae: Aleocharinae). Memoirs of the Entomological Society of Canada No. 129: 1-211.

Klimaszewski J, Langor DW, Work TT, Hammond JHE, Savard K (2008) Smaller and more numerous harvesting gaps emulate natural disturbances: a biodiversity test case using rove beetles (Coleoptera: Staphylinidae). Diversity and Distributions 14: 969-982. doi: 10.1111/j.1472-4642.2008.00517.x

Klimaszewski J, Pace R, Center TD, Couture J (2010) A remarkable new species of Himalusa Pace from Thailand (Coleoptera, Staphylinidae, Aleocharinae): phytophagous aleocharine beetle with potential for bio-control of skunkvine-related weeds in the United States. ZooKeys 35: 1-12. doi: 10.3897/zookeys.35.329

Lawrence JF (1989) Mycophagy in the Coleoptera: feeding strategies and morphological adaptations. In: Wilding N, Collins NM, Hammond PM, Webber JF (Eds) Insect-fungus interactions. 14th Symposium of the Royal Entomological Society of London, Academic Press, London, 1-23.

Makranczy G (2006) Systematics and phylogenetic relationships of the genera in the Carpelimus group (Coleoptera: Staphylinidae: Oxytelinae). Annales Historico-Naturales Musei Nationalis Hungarici 98: 29-120.

Mycoses Study Group (2007) DoctorFungus. http://www.doctorfungus.org

Newton AF (1984) Mycophagy in Staphylinoidea (Coleoptera). In: Wheeler Q, Blackwell M (Eds) Fungus-insect relationships: perspectives in ecology and evolution. Columbia University Press, New York, 302-353.

Newton AF, Thayer MK, Ashe JS, Chandler DS (2000) Staphylinidae Latreille, 1802. In: Arnett RH, Thomas MC (Eds) American beetles. Volume 1: Archostemata, Myxophaga, Adephaga, Polyphaga: Staphyliniformia. CRC Press, New York, 272-418.

Pohl GR, Langor DW, Klimaszewski J,Work TT, Paquin P (2008) Rove beetles (Coleoptera: Staphylinidae) in northern Nearctic forests. Canadian Entomologist 140: 415-436. doi: 10.4039/n07-LS03

Pohl GR, Langor DW, Spence JR (2007) Rove beetle and ground beetle (Coleoptera: Staphylinidae, Carabidae) responses to harvest and regeneration practices in western Canadian montane forests. Biological Conservation 137: 294-307. doi: 10.1016/j.biocon.2007.02.011 
Rivas R, Martens M, De Lajudie P, Willems A (2009) Multilocus sequence analysis of the genus Bradyrhizobium. Systematic and Applied Microbiology 32(2): 101-110. doi: 10.1016/j. syapm.2008.12.005

Robert V, Stegehuis G, Stalpers J (2005) The MycoBank engine and related databases. http:// www.mycobank.org [accessed July 11, 2013]

Seevers CH (1951) A revision of the North American and European Staphylinid beetles of the subtribe Gyrophaenae (Aleocharinae, Bolitocharini). Fieldiana Zoology 32(10): 659-762.

Smetana A (1995) Rove beetles of the subtribe Philonthina of America north of Mexico (Coleoptera: Staphylinidae): classification, phylogeny and taxonomic revision. Memoirs on Entomology, Associated Publishers, Madison, WI, 964 pp.

Suh SO, Blackwell M (2005a) Four new yeasts in the Candida mesenterica clade associated with basidiocarp feeding beetles. Mycologia 97: 167-177. doi: 10.3852/mycologia.97.1.167

Suh SO, Blackwell M (2005b) The beetle gut as a habitat for new species of yeasts. In: Vega FE, Blackwell M (Eds) Insect fungal associations: ecology and evolution. Oxford University Press, New York, 244-256.

Thayer MK (1987) Biology and phylogenetic relationships of Neophonus bruchi, an anomalous south Andean staphylinid (Coleoptera). Systematic Entomology 12: 389-404. doi: 10.1111/ j.1365-3113.1987.tb00209.x

Thayer MK (2005) Staphylinidae Latreille, 1802. In: Beutel RG, Leschen RAB (Eds) Coleoptera, beetles. Volume 1: Morphology and systematics (Archostemata, Adephaga, Myxophaga, Polyphaga partim). Walter de Gruyter, Berlin, 296-344.

Thiffault E, Hannam KD, Paré D, Titus BD, Hazlett PW, Maynard DG, Brais S (2011) Effects of forest biomass harvesting on soil productivity in boreal and temperate forests - a review. Environmental Reviews 19: 278-309. doi: 10.1139/a11-009

Venier L, Thiffault E, Hazlett P, Fleming R, Webster K, Aubin I, Titus B, Arsenault A, Pare D, Klimaszewski J, Kishchuk B, Weldon T, Hawdon L, Curry D, Curry J, Good K, WainioKeizer K (2012) Determining sustainable forest biomass removal rates in Canadian forests. Canadian Forest Service, Research Funded Federal Government Grant BIOI 023.

Wang SA, Li FL, Bai FY (2005) Candida laoshanensis sp. nov. and Candida qingdaonensis sp. nov., anamorphic, ascomycetous yeast species isolated from decayed wood. International Journal of Systematic and Evolutionary Microbiology 60: 1697-1701. doi: 10.1099/ ijs.0.015230-0

White TJ, Bruns TD, Lee SB, Taylor JW (1990) Amplification and direct sequencing of fungal ribosomal RNA genes for phylogenetics. Academic Press, New York, 315-322.

Work T, Klimaszewski J, Thiffault E, Bourdon E, Paré D, Bousquet Y, Venier L, Titus B (2013) Initial responses of rove and ground beetles (Coleoptera, Staphylinidae, Carabidae) to removal of logging residues following clearcut harvesting in the boreal forest of Quebec, Canada. ZooKeys 258: 31-52. doi: 10.3897/zookeys.258.4174 


\title{
Appendix A
}

\author{
Biological notes about some taxa found in staphylinid guts \\ (Fungal classification below is from Mycoses Study Group (2007))
}

\section{Kingdom FUNGI \\ Phylum ASCOMYCOTA}

Ascomycota, also known as sac fungi, is a sister group of the Basidomycota. This group contains the majority of fungi, including yeasts.

\section{Saccharomycetales: Saccharomycetaceae: Candida}

Candida is a yeast and the most common cause of opportunistic mycoses worldwide. It is also a frequent colonizer of human skin and mucous membranes. It is also a pathogen and a colonizer, found on leaves, flowers, in water, and in soil. While most Candida species are mitosporic, some have a known teleomorphic state and produce sexual spores.

\section{Saccharomycetales: Saccharomycetaceae: Cladosporium}

Cladosporium is a dematiaceous (pigmented) mould widely distributed in the air and rotten organic material, and frequently isolated as a contaminant in food. Some species are predominant in tropical and subtropical regions. Some Cladosporium species are isolated from fish and are associated with infections.

\section{Saccharomycetales: Endomycetaceae: Pichia}

Pichia is a teleomorph that produces ascospores. The anamorphs of the Pichia species are various Candida species. The connection of Candida species with their corresponding Pichia teleomorphs is based on observation of the ascospores produced by the Candida isolate or, more specifically, on the $28 \mathrm{~S}$ gene sequence data. Pichia ohmeri was initially isolated from cucumber brine and is commonly used in the food industry for fermentation in pickles, rinds, and fruits. Clinically, Pichia is generally considered to be a contaminant. However, some Pichia species are now recognized as clinically significant opportunistic pathogens.

\section{Eurotiales: Trichocomaceae: Aspergillus}

Aspergillus is a filamentous, cosmopolitan and ubiquitous fungus found in nature. It is commonly isolated from soil, plant debris, and indoor air environment. While a teleomorphic state has been described for only some of the Aspergillus species, others are accepted to be mitosporic, without any known sexual spore production.

\section{Pleosporales: Pleosporaceae: Alternaria}

Alternaria is a cosmopolitan dematiaceous (pigmented) fungus commonly isolated from plants, soil, food, and indoor air environment. The production of melaninlike pigmentation is one of its major characteristics. Its teleomorphic genera are Clathrospora and Leptosphaeria. 


\section{Hypocreales: Hypocreaceae: Acremonium}

Acremonium contains, cosmopolitan filamentous fungi commonly isolated from plant debris and soil. The sexual state of Acremonium is not well-defined. Thus, it is classified among the deuteromycetes group of fungi by some authorities. Others prefer to include it in the phylum Ascomycota, since its structural properties are similar to those of this group.

\section{Phylum BASIDIOMYCOTA}

Basidiomycota contains a wide variety of organisms. It is estimated that there are about 30,000 species in this group. While it is best known for fruiting bodies such as mushrooms, puffballs, and bracket fungi, it also contains microscopical fungi. These include rust and smut fungi, which are both parasites. Basidiomycota fungi are considered to be the most evolutionarily derived of all fungal phyla. Like Ascomycota, the Basidiomycota also contains some forms of yeast. Therefore, the organisms within this classification can be either unicellular or multicellular. There are three major groups within this classification: Urediniomycetes, which includes rusts and other taxa; Ustilaginomycetes, which are largely composed of smuts; and Hymenomycetes, which are composed of mushrooms and jelly fungi.

\section{Sporidiales: Sporidiobolaceae: Cryptococcus}

Cryptococcus is an encapsulated yeast. Following its first identification in nature from peach juice samples, the major environmental sources of Cryptococcus neoformans have been shown to be either soil contaminated with pigeon droppings (Cryptococcus neoformans var. neoformans) or eucalyptus trees and decaying wood forming hollows in living trees (Cryptococcus neoformans var. gattii). Cryptococcus neoformans var. gattii was also isolated from goats with pulmonary disease.

\section{Sporidiales: Sporidiobolaceae: Rhodotorula}

Rhodotorula is a yeast found in air, soil, lakes and ocean water, and dairy products. It may colonize plants.

\section{Kingdom EUBACTERIA Phylum: PROTEOBACTERIA}

\section{Enterobacteriales: Enterobacteriaceae: Serratia}

Serratia marcescens is a motile, short, rod-shaped, gram-negative, facultative anaerobe bacterium classified as an opportunistic pathogen. Serratia marcescens was first thought to be harmless (non-pathogenic). Optimally, S. marcescens grows at $37^{\circ} \mathrm{C}$, but it can grow at temperatures that range from 5 to $40^{\circ} \mathrm{C}$. It grows at $\mathrm{pH}$ levels that range from 5 to 9. Serratia marcescens is well known for the red pigmentation it produces, called prodigiosin. 


\section{Rhizobiales: Bradyrhizobiaceae: Bradyrbizobium}

Members of this genus, including Bradyrhizobium japonicum, are gram-negative soil bacteria that fix nitrogen and are commonly associated with legume plants.

\section{Appendix B}

\section{Hyperlinks for microorganism identification.}

\begin{tabular}{|c|c|c|}
\hline & NCBI Taxonomy Browser & MycoBank \\
\hline \multicolumn{3}{|c|}{ FUNGI, Ascomycota } \\
\hline \multicolumn{3}{|c|}{ Saccharomycetales } \\
\hline $\begin{array}{l}\text { Candida } \\
\text { cretensis }\end{array}$ & $\begin{array}{l}\text { http://www.ncbi.nlm.nih.gov/Taxonomy/ } \\
\text { Browser/wwwtax.cgi?id=268492 }\end{array}$ & $\begin{array}{l}\text { http://www.mycobank.org/BioloMICS.aspx? } \\
\text { Table=Mycobank\&Rec=432161 \&Fields=All }\end{array}$ \\
\hline $\begin{array}{l}\text { Candida } \\
\text { mesenterica }\end{array}$ & $\begin{array}{l}\text { http://www.ncbi.nlm.nih.gov/Taxonomy/ } \\
\text { Browser/wwwtax.cgi?mode=Info\&id=45568\& } \\
\text { lvl=3\&lin=f\&keep=1 \&srchmode=1 \&unlock }\end{array}$ & $\begin{array}{l}\text { http://www.mycobank.org/BioloMICS.aspx? } \\
\text { Table=Mycobank\&Rec }=106492 \& \text { Fields=All }\end{array}$ \\
\hline $\begin{array}{l}\text { Candida } \\
\text { sophiae-reginae }\end{array}$ & $\begin{array}{l}\text { http://www.ncbi.nlm.nih.gov/Taxonomy/ } \\
\text { Browser/wwwtax.cgi?mode=Info\&id=45593\& } \\
\text { lvl=3\&lin=f\&keep=1 \&srchmode=1 \&unlock }\end{array}$ & $\begin{array}{l}\text { http://www.mycobank.org/BioloMICS.aspx? } \\
\text { Table=Mycobank } \& \text { Rec }=105324 \& \text { Fields=All }\end{array}$ \\
\hline $\begin{array}{l}\text { Davidiella } \\
\text { tassiana }\end{array}$ & $\begin{array}{l}\text { http://www.ncbi.nlm.nih.gov/Taxonomy/ } \\
\text { Browser/wwwtax.cgi?mode=Info\&id=29918\& } \\
\text { lvl=3\&lin=f\&keep=1 \&srchmode=1 \&unlock }\end{array}$ & $\begin{array}{l}\text { http://www.mycobank.org/BioloMICS. } \\
\text { aspx?Table=Mycobank\&Rec=411246\&- } \\
\text { Fields=All }\end{array}$ \\
\hline Pichia sp. & $\begin{array}{l}\text { http://www.ncbi.nlm.nih.gov/Taxonomy/ } \\
\text { Browser/wwwtax.cgi?mode=Info\&id=4925\&l } \\
\text { vl=3\&lin=f\&keep=1\&srchmode=1\&unlock }\end{array}$ & $\begin{array}{l}\text { http://www.mycobank.org/BioloMICS.aspx } \\
\text { ?Table=Mycobank\&Rec=97263\&Fields=All }\end{array}$ \\
\hline Pichia delftensis & $\begin{array}{l}\text { http://www.ncbi.nlm.nih.gov/Taxonomy/ } \\
\text { Browser/wwwtax.cgi?mode=Info\&id=3247 } \\
\text { 39\&lvl=3\&lin=f\&keep=1 \&srchmode=1\&u } \\
\text { nlock }\end{array}$ & $\begin{array}{l}\text { http://www.mycobank.org/BioloMICS.aspx? } \\
\text { Table=Mycobank\&Rec=106343\&Fields=All }\end{array}$ \\
\hline $\begin{array}{l}\text { Pichia } \\
\text { misumaiensis }\end{array}$ & $\begin{array}{l}\text { http://www.ncbi.nlm.nih.gov/Taxonomy/ } \\
\text { Browser/wwwtax.cgi?id=131113 }\end{array}$ & $\begin{array}{l}\text { http://www.mycobank.org/BioloMICS. } \\
\text { aspx?Table=Mycobank\&Rec=105848\&- } \\
\text { Fields=All }\end{array}$ \\
\hline $\begin{array}{l}\text { Pichia } \\
\text { membranifaciens }\end{array}$ & $\begin{array}{l}\text { http://www.ncbi.nlm.nih.gov/Taxo- } \\
\text { nomy/Browser/wwwtax.cgi?mode=In- } \\
\text { fo\&id=4926\&lvl=3\&lin=f\&keep=1\&srchmo- } \\
\text { de=1\&unlock }\end{array}$ & $\begin{array}{l}\text { http://www.mycobank.org/BioloMICS.aspx? } \\
\text { Table=Mycobank\&Rec=108031\&Fields=All }\end{array}$ \\
\hline \multicolumn{3}{|l|}{ Eurotiales } \\
\hline $\begin{array}{l}\text { Aspergillus } \\
\text { amstelodami }\end{array}$ & $\begin{array}{l}\text { http://www.ncbi.nlm.nih.gov/Taxonomy/ } \\
\text { Browser/wwwtax.cgi?id=5054 }\end{array}$ & $\begin{array}{l}\text { http://www.mycobank.org/BioloMICS.aspx } \\
\text { ?Table=Mycobank\&Rec=9994\&Fields=All }\end{array}$ \\
\hline $\begin{array}{l}\text { Aspergillus } \\
\text { versicolor }\end{array}$ & $\begin{array}{l}\text { http://www.ncbi.nlm.nih.gov/Taxonomy/ } \\
\text { Browser/wwwtax.cgi?mode=Info\&id=46472\& } \\
\text { lvl=3\&lin=f\&keep=1\&srchmode=1\&unlock }\end{array}$ & $\begin{array}{l}\text { http://www.mycobank.org/BioloMICS.aspx } \\
\text { ?Table=Mycobank\&Rec=2780\&Fields=All }\end{array}$ \\
\hline $\begin{array}{l}\text { Penicillium } \\
\text { spinulosum }\end{array}$ & $\begin{array}{l}\text { http://www.ncbi.nlm.nih.gov/Taxonomy/ } \\
\text { Browser/wwwtax.cgi?id=63822 }\end{array}$ & $\begin{array}{l}\text { http://www.mycobank.org/BioloMICS.aspx } \\
\text { ?Table=Mycobank\&Rec=19325\&Fields=All }\end{array}$ \\
\hline \multicolumn{3}{|l|}{ Pleosporales } \\
\hline Alternaria sp. & $\begin{array}{l}\text { http://www.ncbi.nlm.nih.gov/Taxonomy/ } \\
\text { Browser/wwwtax.cgi?mode=Info\&id=13202 } \\
\text { 40\&lvl=3\&lin=f\&keep=1 \&srchmode=1\&u } \\
\text { nlock }\end{array}$ & $\begin{array}{l}\text { http://www.mycobank.org/BioloMICS.aspx } \\
\text { ?Table=Mycobank\&Rec=31788\&Fields=All }\end{array}$ \\
\hline
\end{tabular}




\begin{tabular}{|c|c|c|}
\hline & NCBI Taxonomy Browser & MycoBank \\
\hline \multicolumn{3}{|l|}{ Hypocreales } \\
\hline $\begin{array}{l}\text { Hypocreales sp. } \\
\text { TR114 }\end{array}$ & $\begin{array}{l}\text { http://www.ncbi.nlm.nih.gov/Taxonomy/ } \\
\text { Browser/wwwtax.cgi?id=929379 }\end{array}$ & \\
\hline $\begin{array}{l}\text { Acremonium } \\
\text { psammosporum }\end{array}$ & $\begin{array}{l}\text { http://www.ncbi.nlm.nih.gov/Taxonomy/ } \\
\text { Browser/wwwtax.cgi?mode=Info\&id=7455 } \\
\text { 71\&lvl=3\&lin=f\&keep=1 \&srchmode=1\&u } \\
\text { nlock }\end{array}$ & $\begin{array}{l}\text { http://www.mycobank.org/BioloMICS.as- } \\
\text { px?Table=Mycobank\&Rec=485\&Fields=All }\end{array}$ \\
\hline
\end{tabular}

\section{FUNGI, Basidiomycota}

\begin{tabular}{l|l|l}
\hline $\begin{array}{l}\text { Cryptococcus } \\
\text { (uncultured) }\end{array}$ & $\begin{array}{l}\text { http://www.ncbi.nlm.nih.gov/Taxonomy/ } \\
\text { Browser/wwwtax.cgi?id=526442 }\end{array}$ & $\begin{array}{l}\text { http://www.mycobank.org/BioloMICS.aspx } \\
\text { ?Table=Mycobank\&Rec=54225\&Fields=All }\end{array}$ \\
\hline $\begin{array}{l}\text { Rhodotorula } \\
\text { mucilaginosa }\end{array}$ & http://www.ncbi.nlm.nih.gov/Taxonomy/ & http://www.mycobank.org/BioloMICS.aspx? \\
Browser/wwwtax.cgi?id=5537 & Table=Mycobank\&Rec=107159\&Fields=All \\
\hline
\end{tabular}

\section{BACTERIA, Protobacteria}

\section{Enterobacteriales}

Bradyrhizobium http://www.ncbi.nlm.nih.gov/Taxonomy/

japonicum Browser/wwwtax.cgi? $\operatorname{mode}=$ Info\&id $=375 \& \mathrm{lvl}$

$=3 \&$ lin $=$ f\&keep $=1$ \&srchmode $=1$ \&unlock

\begin{tabular}{l|l}
\hline Serratia & http://www.ncbi.nlm.nih.gov/Taxonomy/
\end{tabular}

marcescens $\quad$ Browser/wwwtax.cgi? $\operatorname{mode}=I n f o \& i d=615 \& l v l$

$=3 \&$ lin $=$ f\&keep $=1 \&$ srchmode $=1 \&$ unlock 